\title{
Successful small-scale irrigation or environmental destruction? The political ecology of competing claims on water in the Uluguru Mountains,Tanzania
}

\author{
Elizabeth Harrison ${ }^{1}$ \\ Anna Mdee \\ University of Sussex, UK \\ University of Leeds, UK
}

\begin{abstract}
In the Uluguru Mountains of Tanzania, an expansion in informal hosepipe irrigation by small-scale farmers has enabled the development of horticulture, and resulted in improvements in farmers' livelihoods. This has largely taken place independently of external support, and can be seen as an example of the 'private' irrigation that is increasingly viewed as important for sub-Saharan Africa. However, these activities are seen by representatives of government and some donors as the cause of environmental degradation and water shortages downstream, especially in the nearby city of Morogoro. As a result, there have been attempts to evict the farmers from the mountain. Negative narratives persist and the farmers on the mountainside are portrayed as a problem to be 'solved.' This article explores these tensions, contributing to debates about the formalization of water management arrangements and the place of the state in regulating and adjudicating rights to access water. We argue that a focus on legality and formalization serves to obscure the political nature of competing claims on resources that the case illustrates.
\end{abstract}

Keywords: irrigation; Tanzania; ethnography; political ecology; water

\section{Résumé}

Dans les montagnes Uluguru de Tanzanie, une expansion dans l'irrigation de tuyau d'arrosage informel par des petits cultivateurs a permis le développement de l'horticulture, et a donné lieu à l'amélioration des moyens de subsistance des agriculteurs. Cela a eu lieu en grande partie indépendamment de soutien extérieur et peut être considérée comme un exemple de l'irrigation " privé » qui est de plus en plus perçue comme importantes pour l'Afrique subsaharienne. Toutefois, ces activités sont considérées par les deux représentants du gouvernement et des bailleurs de fonds, comme la cause de dégradation de l'environnement et de pénuries d'eau en aval, notamment dans la ville voisine de Morogoro. En conséquence, il y a eu des tentatives d'expulser les cultivateurs de la montagne. Les discours négatifs persistent, et les agriculteurs sur le flanc de la montagne sont dépeints comme un problème soit « résolu ». Cet article explore ces tensions, contribuer aux débats sur la formalisation des modalités de gestion de l'eau et la place de l'État dans la régulation et la sanction des droits d'accès à l'eau. Nous soutenons que mettant l'accent sur la légalité et la formalisation sert à masquer la nature politique de réclamations concurrentes sur les ressources qui illustre le cas.

Mots-clés: irrigation; la Tanzanie; ethnographie; écologie politique; l'eau

\section{Resumen}

En las montañas Uluguru de Tanzania, la expansión del riego informal de mangueras por parte de pequeños agricultores ha permitido el desarrollo de la horticultura y ha dado como resultado mejoras en los medios de

\footnotetext{
${ }^{1}$ Dr Elizabeth Harrison, Reader in Anthropology and International Development, School of Global Studies, University of Sussex, BN1 9PN, UK. Email: e.a.harrison "at" sussex.ac.uk. Dr Anna Mdee, Associate Professor in International Development, School of Politics and International Studies (POLIS) University of Leeds, LS2 9JT, UK. Email: a.l.mdee "at" leeds.ac.uk. Thanks to James Fairhead for comments on this article. Thanks also for useful discussions with Andrew Coulson, Alex Wostry and Janet Maro and the anonymous reviewers for their insightful comments. This work was supported by the DFID-ESRC Growth Research Programme (DEGRP), (grant no. ES/J009415/1: Innovations to promote growth among small-scale irrigators).
} 
subsistencia de los agricultores. Esto ha ocurrido en gran medida independientemente del apoyo externo y puede ser visto como un ejemplo del riego "privado" que cada vez se considera más importante para el África subsahariana. Sin embargo, estas actividades son vistas tanto por representantes del gobierno como por algunos donantes como causa de degradación ambiental y escasez de agua en río abajo, especialmente en la cercana ciudad de Morogoro. Como resultado, ha habido intentos de desalojar a los campesinos de la montaña. Las narrativas negativas persisten y los agricultores de la ladera de la montaña se presentan como un problema que debe ser "resuelto". Este artículo explora estas tensiones, contribuyendo a los debates sobre la formalización de los mecanismos de gestión del agua y el lugar del Estado en la regulación y adjudicación de los derechos de acceso al agua. Sostenemos que un enfoque en la legalidad y la formalización sirve para ocultar la política de las demandas competitivas sobre los recursos que el caso ilustra.

Palabras clave: irrigación; Tanzania; etnografía; ecología política; agua

\section{Introduction}

The Uluguru Mountains are part of the Eastern Arc Mountains in Tanzania and Kenya, and are often described as one of the most important mountainous regions in Tanzania. Apart from their significant fauna and flora, they are an important part of the watershed for Dar-es-Salaam, Morogoro and the Tanga regions. Within the Ulugurus, the Luguru people have practised small scale irrigation since at least the $18^{\text {th }}$ Century (Ulvila 1995). Recently in some areas, irrigation practices have changed; instead of furrows, farmers have begun to use gravity-fed hosepipes to irrigate crops that they sell in the nearby urban centre of Morogoro and as far away as Dar-es-Salaam and Arusha. Strawberries, leafy vegetables, herbs and chillies all have a ready market among the burgeoning Tanzanian middle classes, hotels and expatriate households. From one perspective, this could be considered a good example of sustainable livelihood diversification; farmers are successfully managing a scarce water resource in a low-tech way that is apparently alleviating rural poverty. Some are reinvesting their profits in solar panels; others talk of the livelihood benefits; still others say the new business is helping them to develop ecotourism in the area. The farmers are supported in their endeavors by a range of institutions; a number of local NGOs have worked alongside donors such as DFID, CARE and the WWF in support of the promotion of agroecological farming methods and in piloting 'payments for ecosystem services' (PES) and 'payments for watershed services' (PWS). These seek to reward farmers for conserving water sources in the catchment through the construction of terraces and alternative livelihoods (Lopa et al. 2012; Mussa and Mwakaje 2013; Riel 2013).

However, from another perspective - that of those charged with managing water for the town of Morogoro and ensuring the environmental stability of the mountain - these farmers are illegal water users, polluting the water, destroying a fragile habitat and unfairly stealing a resource from domestic users in the urban areas downstream. The water-supply situation in urban Morogoro is challenging and there are regular shortages. Blame is placed on the Choma farmers who are accused by the Morogoro Municipality and Morogoro Urban Water and Sewage Authority (MORUWASA) of encroaching onto protected land, and harming rather than nurturing the environment. In 2006 the Municipality attempted to evict the farmers of Choma and surrounding villages from the mountain, resulting in protests to the President (Kusulika 2011). The situation is still unresolved. The formal Tanzanian institution responsible for managing water resources, the Wami-Ruvu River Basin Office (WRRBO), insists that, at the very least farmers should obtain permits and pay for their water usage through formal water users associations (WUAs).

This article is an exploration of these contested narratives. It asks what they can tell us about the politics of water access and control, and the institutional management of this. We are interested in how power and resources shape particular institutional and policy configurations (Mosse 2005), and how unequal bargaining power favours the incorporation of some narratives over others (Bues and Theesfeld 2012). This is linked to the debate over the desirability of formalising and regulating water use practices in order to make them legible to (and in turn adoptable by) the state. We explore how legislative frameworks based on formalization are inadequate to resolve competing claims for water allocation, within and beyond particular river basins. Such approaches involve prioritising different types of users and regulating their access accordingly. In this, small-scale farmers with informal access to water can be rendered officially invisible or illegal and may actively resist formalization . The power of smaller-scale farmers to influence or negotiate 
the rules and regulation of water access is limited. Our discussion builds on a tradition of analysis within political ecology and political economy that considers the role of power in processes of adjudication of access to resources (Cleaver 2012; Peluso and Lund 2011). Resource capture by the relatively more powerful is a recurring theme (for example, Eriksen et al. 2015; Taylor 2015).

These questions have more than a theoretical interest. They have particular salience in the context of contested 'solutions' for intersecting questions of climate change, poverty reduction and 'growth' in subSaharan Africa (SSA). With a renewal of interest in agricultural growth as a driver of poverty reduction in SSA, attention has turned to the potential for irrigation to increase the productivity and viability of smallholder agriculture. In Tanzania, while it is certainly the case that water and irrigation management tends to be institutionally plural, there are pressures against this within state policy. The Kilimo Kwanza (Agriculture First) and National Irrigation Policy 2010 (URT 2010) set out a unitary vision of agricultural transformation that is based on a transition from smallholder farming to commercialised investment and production. Such unifying pressures are at odds with the complex realities of contested access to scarce resources, including water (Mdee 2017).

This article is based on a period of nine months fieldwork undertaken during 2013-2014. ${ }^{2}$ The majority of the fieldwork was carried out by Anna Mdee working with locally recruited assistants. It took place both in a rural settlement in the mountains, Choma, and in the urban municipality of Morogoro. Whilst Choma is one small settlement on the Ulugurus, we believe that it illustrates critical issues relating to the politics of water access and the improvement of small scale agricultural livelihoods. Fieldwork was predominantly qualitative, supplemented by a quantitative survey. The qualitative study was comprised of ethnographic observation and semi-structured interviews. Detailed and repeated semi-structured interviews were undertaken with 25 farmers (15 men and 10 women), and with the representatives of the organizations that have come to play a role in their lives. These included the NGO that has been promoting organic agriculture in the area (Sustainable Agriculture Tanzania), an NGO implementing the payment for ecosystem services project mentioned above (Wildlife Conservation Society of Tanzania), the government extension service, academics from nearby Sokoine University of Agriculture, Morogoro Municipal Council, and the formal water management organizations, the Wami-Ruvu River Basin Office (WRRBO) and Morogoro Urban Water and Sewage Authority (MORUWASA). The survey was undertaken with 102 farmers selected through randomised selection on transect walks in the settlement and agricultural plots. Questions sought to uncover basic information on land holdings, water access and agricultural activities, and were then supplemented with more exploratory discussion.

We first describe the promise of informal irrigation and the pressures for formalization that accompany this, and set out our analytical approach to the narratives of environmental destruction and the political coalitions to which they can lead. We then turn to the detail of the case from the Ulugurus.

\section{2. 'Informal irrigation' and the challenges of formalization}

Irrigation in sub-Saharan Africa has a chequered past, and its future is still uncertain. More than 25 years ago, a comprehensive assessment of successes and failures found that achievements had been 'disappointing' and constraints 'severe' (Moris and Thom 1990: 3). The authors noted a general failure to learn from the mistakes of the colonial and immediate post-colonial past. Part of the assessment of past failure relates to the long history of support to larger (and top down) schemes. These have been initiated across the continent since at least the 1920s (the Gezira scheme in the Sudan being an example) and became widespread up to the early 1980s. Apparent failures have been blamed on mismanagement and capture by elites (Mutiro and Lautze 2015; Oates et al. 2015). In recent years, there has been a revived interest in support to irrigation schemes, including the rehabilitation of earlier failures (Mwendera and Chilonda 2013; Veldwisch et al. 2009). Meanwhile the unfulfilled potential of small-scale irrigation to contribute to the transformation of agriculture is SSA has been stressed increasingly (Fujiie et al. 2011; Kadigi 2012; Sakagi and Koga 2011). A

\footnotetext{
2 The research is part of a broader project exploring the institutional aspects of small-scale irrigation (Mdee et al. 2014) and see http://www.sussex.ac.uk/global/research/researchprojects/small_scale_irrigation.
} 
contrast is frequently made between the extent of irrigation in Asia and its correspondingly limited development in SSA. In the $21^{\text {st }}$ Century, while the catalogue of problems associated with formal irrigation schemes, characterised as "build-neglect-rebuild" (Suhardiman and Giordano 2014) continues, there are now renewed hopes for the viability of irrigation that is 'small-scale', 'community-based' and farmer-driven. Such 'private irrigation' is characterised as a 'thriving but overlooked sector' (de Fraiture and Giordano 2014: 167) that has great potential for poverty alleviation and rural development.

Despite this recent recognition, it has long been the case that much irrigation in SSA is not acknowledged as such by those who seek to promote and measure irrigation, precisely because it is not part of schemes and projects, although it may be a vital element of complex livelihood strategies. As Woodhouse points out, water management in SSA involves investments in labor and irrigation technologies, but

...its dispersed nature and its integration into rain-fed cultivation, rather than separation in discrete blocks of irrigated farming, has tended to make it less visible to officials and technical staff trained to differentiate 'irrigated' and 'rainfed' agriculture as separate production systems. (Woodhouse 2012: 784)

This is an important observation, but reveals a tension; if 'less formal' irrigation is recognised as significant, this contributes to an imperative among managers and policy makers to formalize it - to codify the rules, to insist on people signing up to these, to create bureaucracies.

In Tanzania, many of these general patterns are evident. Irrigation is also largely discussed in terms of schemes and the need to attract private investment. So-called 'traditional' irrigation is part of this vision only when it is 'improved' and integrated within formal and bureaucratised systems of water management (URT 2010). Water Users Associations (WUAs) are to be the way that small scale-farmers can access water while customary institutions and informal water use are not recognized. The 2010 Irrigation Policy makes it clear that customary arrangements are to be 'modernized' (URT 2010) through formalization. Approaches to less formal irrigation are therefore often less than supportive, although the picture is complex; as Lein and Tagseth (2009) argue, formal structures of water management in Tanzania are top-down, with strong roots in the colonial past, but current water policy is disjointed and incoherent. They suggest that Tanzanian water policy has elements of populist approaches (through management at the lowest level, creation of participatory water users associations) combined with features of state-centred approaches (River Basin Offices, issuance of permits and rights by the state). In addition within Tanzanian water policy there is also a stated desire for a market approach where water is treated as a tradeable commodity. Rather than interacting in a pluralistic way they suggest that these different policy approaches contradict each other and lead to incoherence in implementation. Lein and Tagseth (2009) also suggest that issues of competing water use are unresolved, and that the preferences of donors and contradictory national policies have created the potential for conflict between different sectors. Whilst the importance of small-scale irrigation in improving the livelihoods of farmers may not be contested, this use of water has to compete with large-scale commercial farmers, thirsty hydropower schemes and rapidly expanding urban populations.

More generally, an evolutionist perspective still tends to dominate much discussion of SSA agriculture (Peters 2013). In this, it is assumed that farmers will evolve from less market-oriented, more 'traditional' practices, to those that are more 'modern', more productive and, importantly, more formally organized. However, the power dynamics of such an evolution tend to remain less examined. Importantly, there is mounting evidence to support the suggestion that the 'bureaucratisation' of rural life that this often entails leads to the consolidation of those in positions of relative strength (see for example Bierschenk et al. 2002; Mosse and Lewis 2006). One important example of this has been the codification of customary tenure concerning land access (Peters 2013; Whitehead and Tsikata 2003). Another relates to codification when it comes to access to and control over water. Cleaver and Toner (2006), Lecoutere (2010) and Potkanski and Adams (1998) amongst others have pointed out that this can favour the more powerful (in terms of their networks of influence) as they are able to shape institutions and formal mechanisms that create outcomes to 
support their interests. Institutional formation is thus recognised as inherently shaped by differential power of the actors concerned. Small-scale farmers, in particular, may be disadvantaged in terms of their access to decision-makers and decision-making spaces. It is also likely that they have inadequate time, resources, knowledge and agency to engage with formal and informal processes of institutional evolution. Participation in institutional evolution can be differentially shaped by structural (age, wealth and gender) and agency (social capital, personal inclination) factors (Cleaver and Toner 2006).

This means that it is not possible to simply uncover the rules by which people manage resources because they may be institutionally creative, including by turning to formalized and bureaucratic mechanisms for negotiating access and resolving conflicts. In addition, those of relatively high power status may be more likely to break existing rules more - and to get away with this. For Lecoutere (2010), among the most important determinants of such higher power status, gender is significant, but does not explain everything. This is a point made by several other commentators (Cleaver and Toner 2006; van Koppen et al. 2012). Additional important determinants might include migration status, education, ethnicity, age and wealth. For Komakech et al. (2012a), the hydraulic position of different users of a water resource is also a key driver of institutional evolution. In their study of the Hingilili sub-catchment in Tanzania, they found that the formalization by the government of property rights to water did not achieve the goal of sustainable and equitable water management. This finding is also pertinent to our case in the Ulugurus, as we develop below.

One significant aspect of people positioning themselves within processes of institutional evolution is that this enables them to support discursive coalitions that provide justifications for action. A well-developed literature has discussed the role of narratives in development (Hajer 1995; Roe 1994). These are stories that come to frame and legitimise particular kinds of intervention or action (Cornwall et al. 2008). They may or may not be 'true', but are significant in that they serve to mobilise both interest groups and resources. Such "discourse coalitions" (Keeley and Scoones 2003) present certain 'facts' as self-evident and generally beyond challenge and they provide a strong motivation for action. Among them, narratives of environmental degradation and scarcity have been particularly significant and have been used to support intervention against those whom are said to be degrading their environment (Scoones et al. 2014). Population growth eroding soils, and people indiscriminately felling trees are narratives that have been debunked by careful and detailed research (Fairhead and Leach 1997; Tiffen and Mortimore 1994). To an extent, this may have resulted in counter-narratives, which suggest that poor people will always look after their environments. But the point is that these narratives fulfil a function; they create coalitions that require action. How coherent these coalitions are is a moot point though; something that also bears examination.

An increasingly important element in this picture is climate change. As Wisner et al. (2012) describe, narratives of water scarcity, environmental destruction and climate change may be used in the politics of resource scarcity and governance. Different interest groups may create such narratives and use them to suit their purpose and their moral understandings of resource use. In Tanzania, they have been used by the politically powerful to justify the removal of those seen to be destroying the environment. For example, Walsh (2012) details narratives of environmental destruction being used in the case of the Ruaha River. These were employed by political and economic interest groups (with little scientific evidence) as a means to evict pastoralists from grazing land, ultimately benefiting tourism operators in the creation of the Ruaha National Park. The narrative (and lived experience) of climate change therefore intersects with the politics of water access, and small-scale irrigation sits in the middle of the claim-making that results.

In considering the competition for the water being used by the farmers on the Uluguru Mountains, we should therefore interrogate the articulation of the evidence presented that argues that the farmers are primarly responsible for environmental degradation. Given the interests of the municipality of Morogoro and even the population of Dar es Salaam in the water resources from the Ulugurus, it is also important to note that water use on the mountains is far from an issue of only local concern and as such the narratives constructed around it take on a greater significance. As Komakech et al. (2012b) have argued for the Pangani river basin, in Tanzania, there is increasing conflict between farmers and city dwellers over access to water. The legal framework consistently favours the urban residents as domestic water supply takes precedence over water for agriculture (URT 2002). These accounts all emphasise an important general point: that water is often more 
than a 'local' resource and moves from place to place. Because of this, an understanding of competing claims also needs to consider how such claims are articulated beyond the local.

\section{Choma irrigation: history and innovation}

The irrigation currently taking place in the Ulugurus above Morogoro follows historical trends, but with some particular examples of innovation. It builds on practices of furrow irrigation that also exist elsewhere in mountainous areas of East and Southern Africa, in Kenya, Tanzania, Malawi, Zimbabwe and Mozambique (Woodhouse et al. 2017). Tanzania itself has a long history of small-scale 'informal' irrigation. Indeed, examples from Tanzania, especially the furrow irrigaiton on the slopes of Mount Kilimanjaro are among the most commonly cited in discussions of the nature and form of such practices in sub-Saharan Africa (for example Adams et al. 1997; Gray 1963; Hillbom 2012; Kemerink et al. 2009; Komakech et al. 2012a,b; Mul et al. 2011; Tagseth 2008). These accounts suggest a situation in which locally specific institutions exist alongside, and interact with, more formalized and bureaucratic state institutions. For example, Hillbom's (2012) account of institutional plurality in irrigation in Mt Meru suggests a functioning system, characterised by technical and institutional continuity over twelve decades despite significant external formal changes (German occupation, British colonial administration and independence). She suggests that agriculture on Meru has developed as 'islands of intensification' driven by population increase, and the shared belief that water is a common pool resource and 'gift from god', but which is also attributed temporary private rights. Interestingly, she notes that in colonial times there were attempts to register and regulate extraction on all irrigation furrows. This was never achieved as the Meru farmers were not interested in formalized rights. Nor are the Luguru farmers in our case study, as we explore below.

Choma, the area at the heart of this ethnography, is part of the Morogoro Municipality, located in a local government ward (kata) known as Mlimani, which includes the settlements of Choma, Mbete, Paku and Mlali. These are no longer official 'villages', but are classified as streets (mitaa) of Morogoro Municipality. The settlements are not within the boundaries of the Uluguru Nature Reserve but on the slopes below the reserve. Figure 1 shows the Uluguru Nature Reserve boundary. Choma is situated close to Morningside. The 2012 National Census data records a population of 4,893 with an average family size of 4.3 for the Mlimani area within which our study area falls (URT 2013). However, there is no accurate population data available for the area known as Choma as the census data is collected at a level of local government above ward level. Nor is it possible to track Choma in earlier census documents as the recording boundaries have been changed. The mtaa (street) secretary for Choma suggested that the number of residents in Choma is in the region of 600 and our survey indicates an average of four people per household (two adults and two children). It is striking that $97 \%$ of our survey respondents reported that they had always lived in their current location. This is confirmed by census data (URT 2013) that suggests that the population is predominantly from the Luguru ethnic group and Muslim and by qualitative interviews that demonstrate strong generational continuity.

On the mountainside, small rivers run throughout the year and there are a number of waterfalls that attract small numbers of tourists. It is these rivers that are used for irrigation. They feed into water catchment tanks at Ruvuma that, along with Mindu Dam, supply water for the Morogoro Urban Water and Sewage Authority (MORUWASA). The terrain is steep and the road up to Choma has previously only been accessible by vehicles up to the primary school at Mbete. In recent years, Choma residents have organized themselves to extend the road further, so that motorcycles will be able to carry people and produce more easily. The walk to Choma from Mbete takes approximately two hours. According to our survey, around two thirds of farmers rely on agriculture alone for their livelihoods, with the remainder combining this with small business activities (for example rolling small cylinder blocks of soil bought for consumption by pregnant women throughout Tanzania), and livestock keeping. Only 3\% have some form of formal employment.

Irrigation has been practiced in Choma for more than a century. However, it has recently undergone changes in technology. Irrigation originally took the form of furrows constructed and maintained by the farmers (Munishi 2008). According to several informants, local government officers began to restrict the use of the old furrow irrigation system with the intention of decreasing agriculture on the Ulugurus. Around ten years ago the farmers began switching to using plastic gravity-fed hosepipes and sprinklers, which had become cheaply available (Figure 2). Farmers weight the hosepipes into the fast running mountain streams 
and this generates high enough pressure to operate small sprinklers. Those we spoke with were overwhelmingly positive about this change in technology, arguing that the furrow system was very wasteful in terms of water use, and that the use of hosepipes significantly decreased their labor requirements. As one farmer put it: "Long ago we were using furrows but the government officials came to destroy them saying that they were using too much water. They haven't tried this since we started using hosepipes" (Farmer interview, July 2013). A number of interviews suggested that one farmer tried out the hosepipe and when others saw his success they began to adopt the method. A very small number of furrows still exist, and those that do are channels direct from the river to small plots of adjacent land. More land is now irrigated as the hosepipes enable access to land that furrows did not reach. Significantly they also individualise irrigation, as the farmer no longer needs to negotiate access to a shared irrigation furrow.

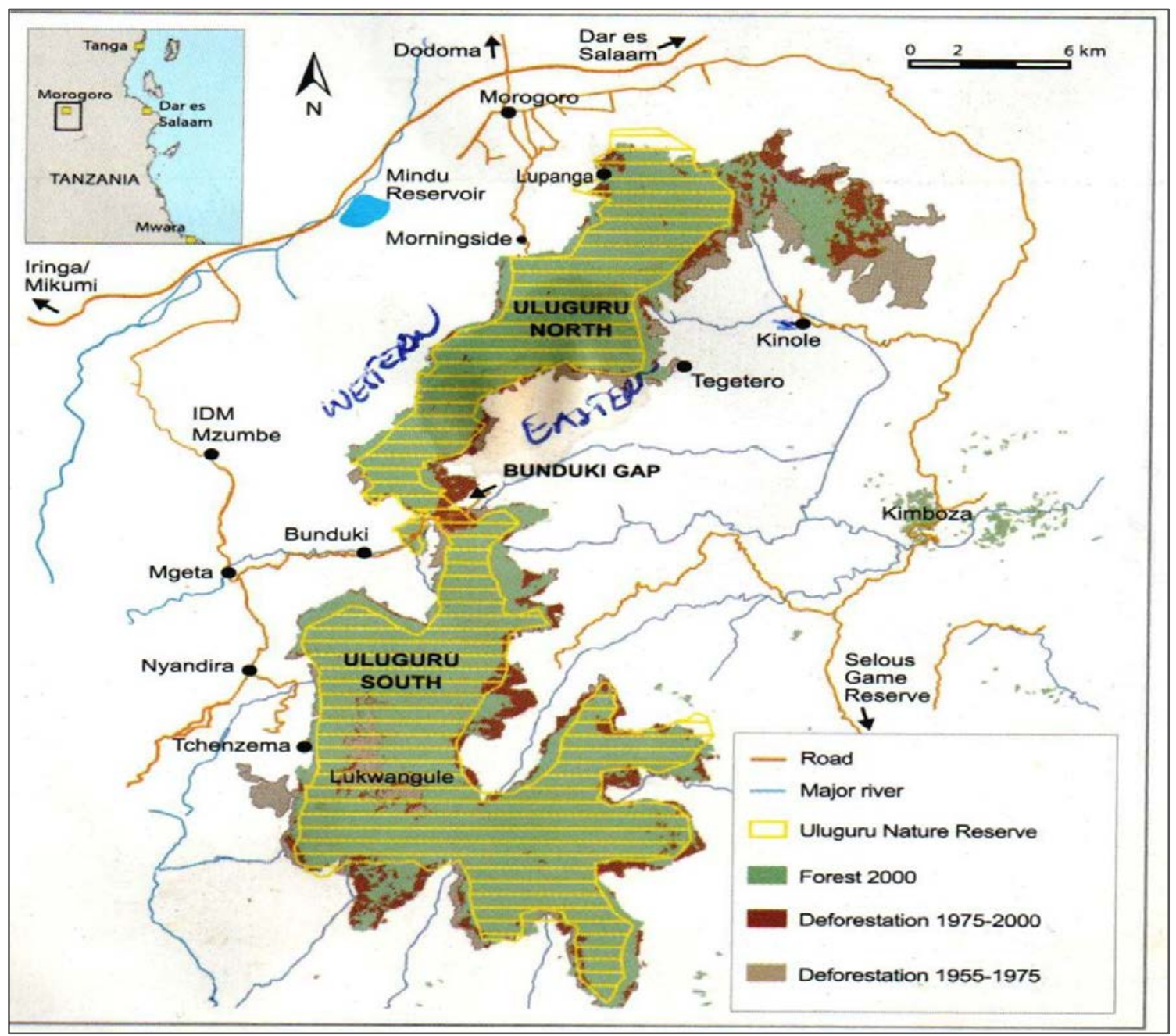

Figure 1: Uluguru Nature Reserve, Source: UNR no date.

Not everybody who wants irrigated land can access it as such access depends on clan relationships to plots as well as physical location of the land in relation to the water sources, and on the technical capacity of 
the hosepipe systems. ${ }^{3}$ Those who can use irrigation are in a position to increase their incomes relative to those who can only farm dry land plots. On the irrigated land, there is a high diversity of vegetable crops, including carrots, celery, onions, lettuce, Chinese cabbages, cabbages, leeks, coriander and others. Fruit crops include tomatoes, peppers, strawberries, raspberries and other berries. Passion fruit, papaya and bananas are also grown. The vegetable and fruit crops have a good market in Morogoro. Farmers often sell direct to expatriates and wealthier local families living in the Forest area of Morogoro. Fruit sellers from the mountains also sell their produce at the door of the more expensive supermarkets. Some farmers working with SAT have collective organic certification and sell their produce in a small shop in town. ${ }^{4}$

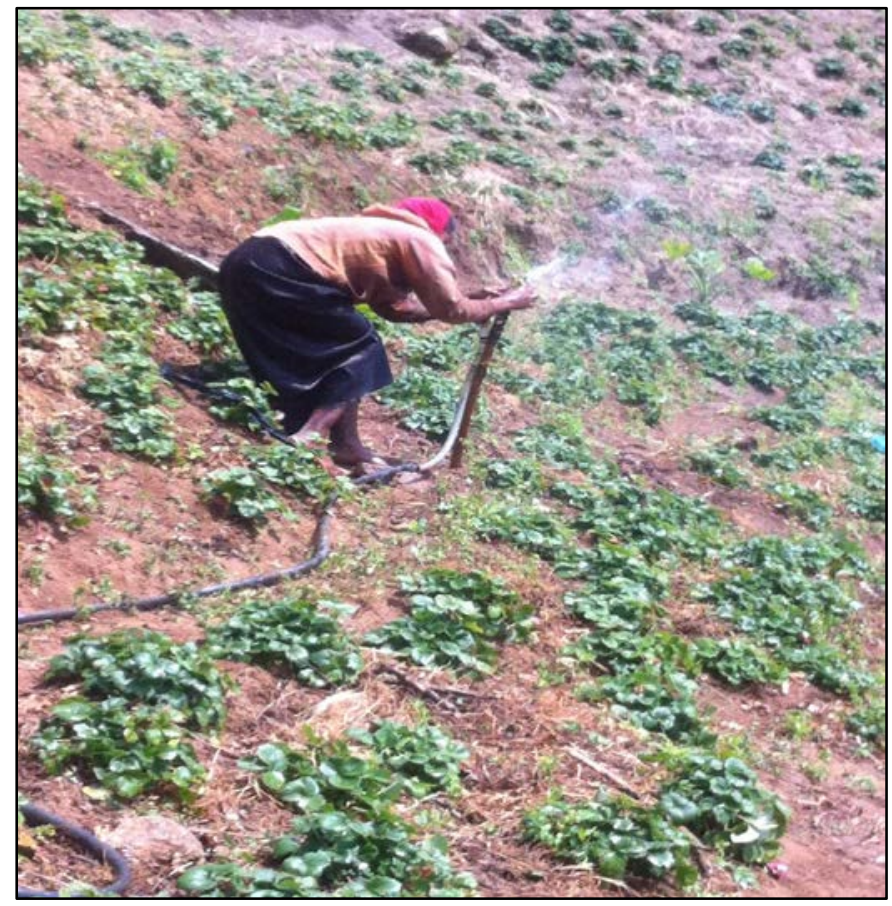

Figure 2: Hosepipe irrigation of strawberry production in Choma

Farmers view strawberries as the most profitable of their crops and these are produced throughout the year. Strawberries are unusual in Tanzania and find a ready market in the big cities of Dar-es-Salaam and Arusha. A small tub can be sold on the street for 3000Tsh (US\$1.50) or to tourists for 5000 Tsh (US\$2.50). At the farm gate, the farmers report that they receive 1,500Tsh (US\$0.75) per bowl. It is difficult to confirm profits as farmers keep no written records, but estimates of gross income made from one acre of strawberries varied from 800,000 - 2 million Tsh (US\$400-US\$1,000). Whilst some young men transport strawberries by bus to Dar and Arusha, others report that buyers now also come direct to the farms. There is no mention of strawberry production in other literature on the Ulugurus, which suggests that it is confined to the Choma area and relatively recent. There is evidence that it began as a cash crop produced by entrepreneurial young men, but that they are now also grown by women. One key informant noted that the Choma farmers seem to have

\footnotetext{
${ }^{3}$ In general, landholdings per household are small and can comprise of several scattered blocks, held by both men and women. Our survey indicated that $97 \%$ of the land is customary freehold and is inherited, although several informants stated that the purchase of small plots is now common. As noted by Bhatia and Ringia (1996), it is still the case that people with no lineage status can borrow or rent land, but now it is also possible to purchase land with the agreement of the relevant clan. However, this is said to be a risky strategy as most land still has no legal title.

${ }^{4}$ This shop is run by Sustainable Agriculture Tanzania who use a participatory guarantee as a form of organic certification.
} 
more money to spend. He cited the example of his own business venture, a small bar and hotel designed to provide accommodation to visitors to the mountains, telling us that: "My wife tells me that we often run out of drinks and our main customers are these farmers from the mountains" (key informant interview, October 2013). At the opening of a new Agricultural Education Centre by Sustainable Agriculture Tanzania, one farmer gave public testament as to the difference in his livelihood through the use of irrigation in combination with organic and conservation techniques. "Since adopting these things I learnt, I have increased my production. I have been able to buy a motorbike and send my children to secondary school" (Farmer speech at official opening ceremony of NGO Farmer Training Centre, October 2013).

Irrigation practice is determined by access to land and capital to purchase hosepipes and sprinklers to tap the water sources. Most farmers spoke of the individual needing to buy and maintain the hosepipes. Sometimes this might be carried out as a joint activity between neighbours, but the arrangement is generally informal:

The one who is responsible for the pipeline is the person themselves. It is their own property. Sharing is important because today you may help somebody and tomorrow you may be helped because nobody knows tomorrow. It is true though that some would like to access water but they fail because they don't have money to buy the pipeline. (Farmer interview, July 2013)

There are no formal bureaucratic rules for water sharing in Choma, but there is evidence of informal arrangements, deeply embedded in the socio-cultural life of the residents shaped through kinship and practiced over many years. Individual farmers purchase hosepipes, but often use them co-operatively with their friends and families. Further interviews with farmers on this issue suggest that they do not reflect on this on being distinctively something of the Luguru, rather they express it as 'normal' cooperation between friends and family, who have lived in the same locations for generations.

Irrigation practice, whilst adopting new technology, is thus embedded in long-standing social relationships, which people do not articulate as formal rules, but as their way of being 'together.' At the same time, water access is constrained by land ownership (through inheritance or through lease or purchase) and technological limitations. New technology has been adopted into these relationships, but government intervention has been actively resisted, as we discuss next.

\section{Narratives of illegality and destruction}

The irrigation practices of the farmers living above Morogoro town appear to have evolved in a way that has improved livelihoods and reduced poverty for a group of farmers whose livelihoods had previously been precarious. However, for a range of people in formal institutions, these practices are environmentally destructive and illegal and should be stopped - or managed and controlled. This builds on a long history of narratives of environmental destruction in the Ulugurus as described by, for example, Jones (1996) and Van Donge (1992), but has found a new target in the activities of the irrigating Choma farmers.

Accounts suggest that the Luguru people first settled on the mountains in the 17th century (Ulvila 1995), moving in significant numbers in the 19th century due to violence in the lower plains. Forests were cleared for agriculture through burning, creating fields on the steep slopes. Coniat et al. (1997) suggest that by 1871 the population levels were high and systems of irrigation were in place. Under the German Occupation, a forest reserve was created in 1909 and local farmers were expelled. There were already concerns that the rapid clearance of the forest could lead to the destruction of water sources. This expulsion put further pressure on land for farming. Attempts to establish coffee growing were not successful, with farmers preferring to produce vegetables using irrigation (Lyamuya et al. 1994).

Concerns about the environmental impact of settlement and farming in the Ulugurus have a similarly long history. For the period from 1930-1990, accounts suggest that land clearance and cultivation were causing significant erosion, leading to regular landslides and considerable fluctuations in river levels (Jones 1996; Lundgren 1978; Temple 1972; Ulvila 1995; Van Donge 1992). In 1953, the British enforced a programme of terracing and other soil conservation measures to counteract the erosion, but this was resisted 
by the Luguru and blamed for an increase in hunger (Temple 1972). As Jones (1996: 188) notes, "...a typically Malthusian image was conveyed by agricultural officers, who suggested that the Uluguru Mountains were carrying a heavier population that the soils could sustain." In the early $21^{\text {st }}$ Century, the narrative that responds to predictions of environmental decline is that of payment for ecosystems services (PES) and payment for watershed services (PWS) which incentivise farmers to undertake environmental conservation with payment for specific activities such as terracing and other aspects of water management (Lopa 2012; Mussa and Mwakaje 2013; Riel 2013). Research by Sustainable Agriculture Tanzania suggests that there now exists a high level of willingness amongst some farmers to build terraces as part of a conversion to organic agricultural production as they realize their value in increasing agricultural production (Wostry 2014). This activity can be seen in Choma, but also more widely in the Ulugurus.

As noted, the key institutions involved in regulating water use on the mountainside include the Morogoro Municipality, the Wami-Ruvu River Basin Office (WRRBO), which has legislative responsibility for water rights, and MORUWASA, which is responsible for urban water supply. However, accounts of competing water use on the Ulugurus are also influenced by the wider urban and regional politics of water supply, not just in Morogoro, but also in Tanzania's most rapidly expanding and most thirsty city, Dar-esSalaam (Kwayu et al. 2014). The perspectives of these local level institutions thus intersect with national policy and political interests to make for a complex politics.

Narratives critiquing the farmers focus on a combination of rule-breaking and environmental destruction. For example, we were told:

They have created their own way of irrigation that the government does not approve of. The use of hosepipes is against the law and so they do this illegally. The rule is that they are not allowed to farm within 60 metres of the water sources. However none of the residents comply with this. (Ward Executive Officer, September 2013)

The 2009 Water Resources Act stipulates that all water rights are issued by the relevant River Basin Office, and that rights can only be issued to formal groups or individuals for a specified intake (URT 2009b). Morogoro Municipality however went further than simply branding the irrigation in Choma as illegal. The Director of the WRRBO suggested in interview that: 'permits could not be issued for hosepipes as they are not connected to a specified intake, and are therefore illegal'. In 2006-2007 Morogoro Municipality attempted to evict the Luguru from Choma and surrounding villages. ${ }^{5}$ Interviews with Ward Executive Officers report on how they were ordered by the Municipal Council to tell the farmers that they had been allocated land in a lowland area on the edge of Morogoro.

In 2006/7 there was a huge conflict between the government and the residents from Choma and surrounding areas as the government tried to remove them without consultation. This caused a huge row which ended with the residents going to the President to resist this move. Two years later (2009) they were told that they can stay under certain conditions that they should look after the environment and work with the NGOs. (Ward Executive Officer, October 2013)

Farmers reacted angrily at the public meetings. Interviews attest to their dismay and unhappiness at being told to leave their lands. As one put it:

It is true that the Municipal Government wanted to move us but they couldn't provide a logical reason and that is why we refused to move. They keep bringing new reasons such as we are destroying the water sources and they say we build houses and plant crops too near to the river. (Farmer interview, October 2013).

\footnotetext{
${ }^{5}$ The residents of these areas were a particular target as their land borders the rivers which partly provide water to urban Morogoro.
} 
Another said that:

Since the colonial times, we are the ones who have been preserving this environment without the assistance of the government. That is why you still see a greenish environment here. To shift us from our homes here would be to end our lives. I would rather die than to move to that place at Kegea. (Farmer Interview, November 2013)

Following this resistance the Council proposed that no land should be passed on to the children of residents and that they must take land on the new plots in the lowlands. The Choma Luguru clans formed a committee to fight the threat of eviction. Families made contributions to a collective fund to pay for some of the farmers to go to Dar es Salaam and make a representation to the Prime Minister (Edward Lowassa). Access to the Prime Minister was negotiated through a senior academic from Sokoine University of Agriculture, who accompanied them on the visit. It is said that, having been made aware of the situation, the then Tanzanian President, Jakaya Kikwete directed the Mayor of Morogoro that the people could not be moved unless compensation were made available. However, it is not clear if the threat has really disappeared; interviews with those involved in the eviction discussions in Morogoro suggest that the Municipal Council Task Force working on this issue would still like to move the farmers but cannot raise the necessary compensation:

The cost of moving those people is too high and is made difficult by the background politics. I am on the task force of the Municipal Council and even last week we discussed this. We talked about the options and think about 10,000 families should move so the costs of compensation are very high. (Key informant interview, Task Force Member, September 2013)

Hence the current position is that if the farmers cannot be forced to move off the mountains, then they need to be taught to farm in an environmentally sustainable way. This work is seen to be the job of NGOs, rather than of government agricultural extension officers. And it is framed, by government officials, as a job that is made difficult by the 'resistance and selfishness of the farmers'.

The main barrier is knowledge exchange, especially when there has been seminar and training. There is a lack of co-operation, there is no willingness to comply with the new farming techniques that are aiming to conserve the water source since their prime intention is to use water for their farming and not for the people of Morogoro. Also the accessibility to the area is very restricted and those people have a lack of education so it is difficult to explain and to make them understand the benefits. (Ward Executive Officer interview, September 2013)

In contrast, our fieldwork suggests that farmers are indeed open to learning in relation to environmentally sustainable practices and are using a high level of environmentally sensitive techniques. Of those in our survey, $85 \%$ reported using conservation tillage in the form of terraces, 53\% use legume incorporation (particularly on rain-fed land), 62\% practice crop rotation and $84 \%$ are incorporating manure or compost on to their land. More than $85 \%$ said that what they had learnt had a positive effect on productivity. There is also a willingness to learn and practice terracing and water/soil conservation techniques:

NGOs come to talk to us on good farming practices. They provide important information on contours, organic farming. This is good information which we can use. I believe a good farmer is one who can farm organically and using conservation tillage on the mountainsides. They are the best as chemicals have negative impacts on the environment and can even poison the consumers. (Farmer interview, July 2013) 
This willingness of farmers to adapt conservation practices appears to contradict the environmental destruction narrative. Farmers want to stay on their lands, they want their children to be able to farm and they want to derive a reasonable livelihood. Farming in a sustainable way is in their self-interest. However, other sources speculated on the political nature of the scheme, and suggested the attempted eviction was an early attempt to start moving all farmers from the entirety of the Ulugurus, with this connected to the wider landscape of hydro-politics in Tanzania.

The Mayor of Morogoro told me about the pressure that was put on him to move the people from the mountain. The problem is that the Ulugurus are vulnerable as they provide the water for Dar. The parliamentarians are getting pressure from the big industries such as Coca Cola and Tanzanian Breweries to increase the water supply, but they are also the ones who should be paying to conserve the environment in the catchments. (Academic key informant interview, October 2013).

It is certainly the case that the politics of water and water scarcity are hot topics and in turn reflect the power relations between those articulating their positions. The vocal urban population in Dar es Salaam suffers from water shortages and coverage in the media keeps this issue to the fore. ${ }^{6}$ Payment for Ecosystem/Environmental Services (PES) projects were seen as a way for the urban business interests to pay for upstream conservation of water sources. Kwayu et al. (2014) note that in an attempt led by WWF/CARE to implement this approach, only the nationalised Dar-es-Salaam Water Company (DAWASCO) and Coca Cola Kwanza Ltd have made limited commitments to contribute to pilot schemes. which are no longer in operation. Donors in the area in general have been more keen on such apparently persuasive measures than the coercive approach adopted by the Municipality, and were reportedly not involved at all in the eviction attempt. This in turn resonates strongly with a Tanzanian past in which the legacies of forced movements of people are strong (Greco 2016).

Farmers on the Choma side of the mountains are not vulnerable to the pressure for more water in Dares-Salaam; rather it is their position immediately upstream of the growing Morogoro Municipality that makes them a subject for concern. Farmers are thus still being targeted for removal from the mountain and are blamed for the declining water supply to Morogoro. The history of environmental management on the Uluguru Mountains suggests that local farming practices have been characterized as damaging and unproductive for many years. Blaming the farmers for destruction of the environment and hence being the root cause of water shortage in the urban area is thus currently politically convenient and builds on this legacy.

Such blame may be politically convenient, but is it correct? In the account above, we have not addressed one important and obvious question: what if it is true? What if the farmers really are depriving Morogoro of drinking water or carrying out unsustainable farming? While this question has not been the central concern of this article, it is worth noting that the evidence is at the very least mixed. While there is, as noted, a literature which discusses the broader questions of environmental management in the Ulugurus, the precise effects of the spread of agriculture through hosepipe irrigation has not been formally assessed. It is certainly the case that farmers do not mention any concern for domestic water supplies to Morogoro, other than referring to government criticisms of the furrow system as wasteful. Field observations also suggest that there is at least some erosion taking place where farming is practiced on very steep slopes. As noted, donorsupported NGOs have responded to this with the encouragement of terracing, both with incentive payments and without (Wostry 2014).

However, it is certainly unclear if the small-scale hosepipe irrigation is really significant with regard to urban water supply - the ostensible reason for the attempted eviction. Rather it is possible that the really problematic water use is in larger scale construction of dwellings on the lower slopes of the mountains. Here, land is increasingly in demand for building plots by wealthier urban dwellers, although these developments

\footnotetext{
${ }^{6}$ http://www.dailynews.co.tz/index.php/home-news/44294-dar-water-supply-set-to-reach-756-litres-by-2017
} 
are often considered to be illegal by the Morogoro Municipal Council. One MORUWASA official argued that:

People are living very close to the intake and they are diverting the water- they are taking more than 50\%. In 1999 there were only about 500 people living there and then the government built schools, a hospital and brought electricity. This has encouraged people to come and build.

A senior official from WRRBO also suggested that:

There are many illegal constructions in the mountains and we need to preserve the water sources, but also even big institutions like the Universities and Army bases have not been regulated for their water use. We have not been able to do this as yet.

It is not within the scope of this article to map out the scale of the development of new housing, but it was a common theme in interviews with key stakeholders and may well be a contributory factor in the current problems of urban water supply. In common with other similar urban settlements in Tanzania, Morogoro is expanding rapidly and demand for water is increasing (see Smiley 2013 for a discussion of urban water demand).

\section{Control and formalization}

Informal and farmer-led irrigation is often rendered invisible to policy makers and planners (Woodhouse et al. 2017). However, attempts to formalize and regulate this type of irrigation are not straightforward. Whilst the aim of evicting the Luguru from the mountainside has so far been unsuccessful, it has also been accompanied by discussions of formalization in order to codify and regulate water access by the farmers. Such codification presents particular challenges for the irrigating farmers. But it also illustrates the complexity of responsibilities for regulating and controlling water access. Thus, rather than a simple dichotomy between farmers on the one hand, and the 'state' on the other, we find a more complex configuration of interests.

In a discussion of conflicts over land in Africa, Peters (2013) argues that tenure formalized through colonial systems actually makes the poorest more vulnerable to state and elite land appropriation. This same vulnerability could be applied to customary access arrangements for water. Those who resist formalization are branded as illegal water users and therefore vulnerable to losing their access. As noted above, national policy in Tanzania prescribes registration and control of water use by all users and stipulates that all water users should apply for permits from the relevant river basic office (Lein and Tagseth 2009; URT 2009b). Although permits can be issued individually, in practice the WRRBO is very reluctant to do this and prefers that smallholder farmers are organized into associations (WUAs).

In practice, this state control does not operate as policy prescribes; in the Ulugurus, there are certainly contradictory views over who should be managing the water. Formally, the legislative responsibility for water permits sits with the Wami-Ruvu River Basin Office (WRRBO). However, several local government officials indicate that they think that it sits with MORUWASA. The 2009 Water Resources Act assumes that WUAs will be in place so as to effect a formal process of conflict resolution between water users. However, in reality the formation and registration of WUAs is constrained by a lack of resources. A senior official of WRRBO argued that registration would make it much easier for WRRBO to work with people on managing the water sources and resolving conflicts. They said that WRRBO has supported the formation of two WUAs in the mountains, but that it does not cover the Choma area. Whilst the WRRBO admits it does not have the resources to cover Choma, MORUWASA argues correctly that water catchments are also not its responsibility; it buys water rights from WRRBO and sells water to domestic and commercial customers in Morogoro Municipality. The WRRBO also wants to formalize arrangements and make farmers pay for water. However, it was suggested by the Director of WRRBO that the current legislative framework would not enable the WRRBO to issue permits for the multiple intake hosepipe system that the farmers in Choma use, 
and that they only issue a permit for a single intake. In fact, the legislation does allow for individual permits to be issued. However, it appears that there is little incentive for WRRBO to issue permits to small-scale users such as the Choma farmers. Van Koppen et al. (2016) point out that the 30 largest users in the Wami-Ruvu River Basin use $89 \%$ of the water (and provide, hence, $89 \%$ of the tax). The 930 other users (both individuals and some collectives) use $11 \%$. Therefore the cost of issuing permits to multiple small farmers would exceed the revenue generated in permits.

The farmers in Choma do not see any value in organising themselves into a WUA. An NGO key informant noted the local resistance to formalization of water access, arguing that: "The approach that WRRBO is taking is to tell them to pay their bills. They are supposed to establish a Water Users' Association but the people are resisting to pay" (key informant interview, September 2013). Farmers themselves do not distinguish between Morogoro Municipality, MORUWASA and WRRBO: all are 'government' who attempt to control them with limited justification. As one farmer put it: "what has the government ever done for us? We can do perfectly well without them." Another told us: "If the government comes here and tells me to pay a fee for water, then I will not pay it. Even if they were to come and provide hosepipes, I can manage on my own" (farmer interviews, July 2013).

The Choma farmers are proud of their agricultural productivity, they care for the environment and are distrustful of government. Ideas of being Luguru remain strong and the population of Choma is fairly homogenous in our survey, in relation to land holdings (average land holding of 2.5 acres (1ha) with a range of 0.25-7 acres (0.1-2.8ha) and ethnic origin (97\% Luguru and resident since birth). This is further confirmed by interviews with farmers who explain their management of water in terms of cooperative kin based relationships. Of course government institutions need to consider the wider use of water beyond the local level, and the desire to formalize water users through bureaucratic associations is understandable. However there could be an argument for exceptions where pre-existing arrangements remain dominant in practice, and where the administrative cost of issuing the permit outweighs the revenue generated.

The challenge and paradox for the informal nature of water use by the Choma farmers is that they have little visibility and representation as a group whilst they continue to be informal. They have no official voice within the institutions that manage water and those institutions have no official mechanism through which to negotiate with them. It is not clear what might happen if the farmers were to become officially organized as a WUA. There is evidence from elsewhere that local elites (such as local politicians, former civil servants, religious leaders, wealthier community members tend to use such associations to formalize their own power (Cleaver and Toner 2006). This could become a mechanism to reduce Luguru control over both land and water. On the other hand it may be that formalization would give at least some farmers the ability to contest and engage with those who currently dismiss them as ignorant and destructive. From the point of view of the formal institutions the farmers would become more legitimate in certain ways. But their position is clearly precarious, especially as they also need to demonstrate a compliance with the narrative of environmental conservation including the way it is currently manifested in PES in order to remain on the mountainside.

Yet, aside from the issue of whether the Choma farmers are formalized or choose to formalize their water-sharing arrangements, the case reveals a much bigger issue. Even if the Choma farmers were to create a WUA, the problem of how to balance the needs of competing water users at different hydrological positions remains. This is technically the role of the WRRBO, which under the 2009 Act issues permits that include a calculation of water to be used under that permit. However, our evidence suggests that monitoring of the allocations does not take place, as the WRRBO has no resources to do this. Nor is there a mechanism through which the assessment of competing water uses can be assessed or debated. There are hints in the 2002 Water Policy that suggest a prioritisation of uses (i.e. domestic use is prioritised over agricultural use), but how competing uses might be balanced is unclear. This is critical in seeking to resolve the tensions in the Choma situation, where the upstream farmers compete for the same water that is used to fill swimming pools in Morogoro. So not only is there a problem of current physical scarcity of the water, but also a political dimension relating to legitimacy of water use. Water allocation is not a zero-sum game. Physical scarcity could be addressed through increased collection and storage capacity, but this requires resources for investment. However, in the current situation of urban water shortage, there is considerable doubt as to the capacity of WRRBO to strategically manage water resources between competing users, whilst they seek to 
increase supply. As one WRRBO employee said in brushing off a request for an interview: "we just sell water- that is all we do!"

\section{Discussion and conclusions}

The state institutions managing the water from the Ulugurus do not know if the farmers are using too much water, as they do not know how much water they use. They would not know this even if the farmers were formalized as a WUA, as they currently do not measure actual water extraction levels, but this would enable them to then sell water to the farmers. It is difficult then to see what purpose WUAs might serve other than to enable the River Basin Office to extract payments from them. This finding echoes that of Komakech et al. (2012a) in the Pangani river basin. There is no doubt that water resources are in high demand and hold much promise: they could transform agriculture, supply the growing urban population and generate power (Kadigi et al. 2011). However, as the case of the Choma farmers and Morogoro Municipality demonstrates, they may not be able to satisfy every demand, without significant investment in water collection and storage capacity. The legitimacy of access to use water is thus contested and will become increasingly so as demands grow.

As our case confirms, water scarcity is not just a technical supply constraint (although technical supply is also critical) but is also politically constructed (Allouche et al. 2015). We are not arguing that the smallscale farmers automatically have a right to access the water, given the advantage of their hydraulic position. Our argument is that competing claims require negotiation and ultimately adjudication. Our evidence suggests that the shortage of water for the urban population of Morogoro is blamed on small-scale farmers causing environmental destruction and over-extracting water. We have shown how the water use and farming practices of the farmers are labelled as destructive, polluting and illegal, to the extent that they warrant the creation of a Task Force to address them as a problem that would ideally lead to their eradication from the mountain. Senior officials in the River Basin Office admit that other water uses (including residential building and large institutions) are contributing to a current shortage of supply to Morogoro town, but they are not presented as a problem in the same way as the small-scale farmers are. We also know that this view of the small-scale farmer has both historical and geographical precedent in Tanzania and the option of eviction is also embedded in the legacies of forced resettlement. It is striking that the Task Force charged with addressing these issues considers only the water use of the small-scale farmers high up in the catchment and does not consider the catchment as a dynamic system - or the nature of water use in urban Morogoro.

The Tanzanian state currently does not have a working institutional mechanism to resolve these competing demands for water. Existing legislation seeking to formalize water users is only partially applied and, as we see in the case of Choma, often resisted (see also Hilbom 2012). Permits are also a weak form of management of water resources for rivers, given their variability in water level. Our case therefore shows that the challenge is not necessarily so much one of formalization but one of responsive political decision-making. The Choma farmers are doing well: they are using irrigation to increase their productivity and improve their livelihoods. Is there a way for them to continue to do this whilst also ensuring that the urban population have enough water to drink, wash and cook with?

In Choma, small-scale and informally organized farmers are marginalised from more formal and bureaucratised water resources management mechanisms, and can be discriminated against by narratives that seek to brand them as environmentally destructive or wasteful. These tap into both well-established discourses and more recent concerns about climate change. In our case, the blame is placed squarely with the farmers rather than in the generalised narratives of climate change discussed by Walsh (2012). However, climate change is an important part of the background to this situation. Choma is one village on the Ulugurus, but we believe a political ecological analysis can shed light on wider theoretical concerns. We suggest that formalization of this informal water use will not be a solution to resolving competing tensions over water use, because processes of formalization may often disadvantage those who are subject to them (Eriksen 2015). But this is not simply a matter of resource capture by the more powerful; it is also about institutions at a range of levels that are simply not in a position to do the tasks with which they are nominally charged. There is no easy fix to this, as institutional capacity reflects histories and resource access, but starting with analysis of local politics and power over competing claims to water is an important step. 


\section{References}

Adams, W.M. and D. Anderson. 1988. Irrigation before development: indigenous and induced change in agricultural water management In East Africa. African Affairs 87(349): 519-535.

Adams, W.M., E. Watson and S. Mutiso. 1997. Water, rules and gender: water rights in an indigenous irrigation system, Marakwet, Kenya. Development and Change 28(4): 707-730.

Allouche, J., C. Middleton and D. Gyawali. 2015. Technical veil, hidden politics: interrogating the power linkages behind the nexus. Water Alternatives 8(1): 610-626.

Bhatia, Z. and O. Ringia. 1996. Socio-economic survey of selected villages in the Uluguru Mountains, Tanzania. Uluguru Slopes Planning Project Report No. 3. Morogoro, Tanzania: Government of Tanzania, EU and Royal Society for Protection of Birds UK.

Bierschenk, T., J-P. Chauveau and J.P. Olivier de Sardan. 2002. Local development brokers in Africa: the rise of a new social category. Arbeitspapiere/Working Papers No. 13. Mainz: Inst. für Ethnologie und Afrikastudien.

Bues, A. and I. Theesfeld. 2012. Water grabbing and the role of power: shifting water governance in the light of agricultural foreign direct investment. Water Alternatives 5(2): 266-83.

Cleaver, F. and A. Toner. 2006. The evolution of community water governance in Uchira, Tanzania: the implications for equality of access, sustainability and effectiveness. Natural Resources Forum 30: 207-218. Academia

Cleaver, F. 2012. Development through bricolage: rethinking institutions for natural resource management. London: Routledge.

Coniat, D. and J-P. Raison. 1997. Utilisation du sol et amenagement de l'espace dans le Haut Mgeta (Monts Uluguru). In Raison J-P. (ed.) Essais sur les montagnes de Tanzanie. Paris: Karthala-IFRAGeotropiques. Pp. 228-263.

Cornwall, A., E. Harrison and A. Whitehead, 2008. Gender myths and feminist fables and the struggle for interpretive power in gender and development. Oxford: Blackwell.

de Fraiture, C. and M. Giordano. 2014. Small private irrigation: a thriving but overlooked sector. Agricultural Water Management 131: 167-174.

Eriksen, S.H., A. Nightingale and H. Eakin. 2015. Reframing adaptation: The political nature of climate change adaptation. Global Environmental Change 35: 233-333. Researchgate

Fairhead, J., and M. Leach (eds.). 1998. Reframing deforestation: global analyses and local realities. New York: Routledge.

Fujiie, H., A. Maruyama, M. Fujiie, M. Takagaki, D. Merrey, and M. Kikuchi. 2011. Why invest in minor projects in sub-Saharan Africa? An exploration of the scale economy and diseconomy of irrigation projects. Irrigation and Drainage Systems 25(1): 39-60. Researchgate

Gray, R.F. 1963. The Sonjo of Tanzania: an anthropological study of an irrigation-based society. London: Oxford University Press.

Greco, E. 2016. Village land politics and the legacies of ujamaa. Review of African Political Economy 43(s1): 22-40.

Hajer, M. 1995. The politics of environmental discourse: ecological modernisation and the policy process. Oxford: Clarendon Press.

Hillbom, E. 2012. When water is from God: formation of property rights governing communal irrigation furrows in Meru, Tanzania, c. 1890-2011. Journal of Eastern African Studies 6(3): 423-443.

Jones, S.J. 1996. Degradation discourses in the Uluguru Mountains, Tanzania: evolution and influences. Journal of Rural Studies 12(2): 187-199.

Kadigi, R., M.J., S.Y. Ntengua, G. Mdoe, G.C. Ashimogo, and S. Morardet. 2008. Water for irrigation or hydropower generation? Complex questions regarding water allocation in Tanzania. Agricultural Water Management 95: 984-992.

Keeley, J and I. Scoones (eds.). 2003 Understanding environmental policy processes: cases from Africa. London: Earthscan. 
Kemerink, J.S., R. Ahlers and P. van der Zaag. 2009. Assessment of the potential for hydro-solidarity within plural legal conditions of traditional irrigation systems in northern Tanzania. Physics and Chemistry of the Earth 34: 881-889.

Komakech, H.C., P. Van der Zaag, M. Mul, A. Tulinumpoki, A. Mwakalukwa, and J.S. Kemerink. 2012a. Formalization of water allocation systems and impacts on local practices in the Hingilili subcatchment, Tanzania. International Journal of River Basin Management 10(3): 213-227.

Komakech, H.C., M. Condon, P. van der Zaag. 2012b. The role of statutory and local rules in allocating water between large- and small-scale irrigators in an African river catchment. Water SA 38(1): 115-126.

Kusiluka, M., S. Kongela, M. Kusiluka, E. Karimuribo, and J.M. Lughano 2011. The negative impact of land acquisition on indigenous communities' livelihood and environment in Tanzania. Habitat International 35(1): 66-73.

Kwayu, E., S. Sallu and J. Paavola. 2014. Farmer participation in equitable payment for watershed services in Morogoro, Tanzania, Ecosystem Services 7:1-9. Draft

Lein, H., and M. Tagseth. 2009. Tanzanian water policy reforms - between principles and practical applications. Water Policy 11(2): 203-220.

Lecoutere, E. 2010. Institutions under construction. Resolving resource conflicts in Tanzanian irrigation schemes. Microcon Research Working Paper No. 23. Brighton: MICROCON.

Lopa, D., I. Mwanyoka, G. Jambiya, T. Massoud, P. Harrison, M. Ellis-Jones, T. Blomley, B. Leimona, M. van Noordwijk and N. Burgess. 2012. Towards operational payments for water ecosystem services in Tanzania: a case study from the Uluguru Mountains. Oryx 46(1): 34-44. Researchgate

Lundgren, L. 1978. Studies of soil and vegetation development on fresh landslides scars in the Mgeta Valley, Western Uluguru Mountains, Tanzania. Geografiska Annaler 60(A): 91-127.

Lyamuya, V. E., L.G. Noah, E. Kilasara and N. Burgess, 1994. Socio-economic and land use factors affecting the degradation of the Uluguru Mountains catchment in Morogoro Region, Tanzania. Regional Natural Resources Office Morogoro, RSPB - UK.

Mdee, A. with E. Harrison, E. Bahati , C. Mdee, and E. Mdee. 2014. The politics of small-scale irrigation in Tanzania: making sense of failed expectations. Future Agricultures Consortium Working Paper No. 107. Brighton: Future Agricultures Consortium.

Mdee, A. 2017. Disaggregating orders of water scarcity - the politics of nexus in the Wami-Ruvu River Basin, Tanzania. Water Alternatives 10(1): 100-115.

Moris, J. and D. Thom. 1990. Irrigation development in Africa: lessons of experience. Boulder, Colorado: Westview Press.

Mosse, D. 2005. Cultivating development: an ethnography of aid policy and practice. London: Pluto Press.

Mosse, D and D. Lewis (eds.). 2006. Development brokers and translators: the ethnography of aid and agencies. London: Kumarian Press.

Mul, M.L., J.S. Kemerink, N.F. Vyagusa, M.G. Mshana, P. Van der Zaag and Makurira, H. 2011. Water allocation practices among smallholder farmers in the South Pare Mountains, Tanzania: the issue of scale. Agricultural Water Management 98(11): 1752-1760.

Munishi, P., Y. Ngaga and G. Soka. 2008. Socio-economic, cultural and livelihood factors influencing local people's participation in water resource management in the Uluguru mountains, eastern Tanzania. Tanzania Journal of Forestry and Nature Conservation 78(1): 43-53. Researchgate

Mussa, K.R. and A.G. Mwakaje. 2013. The impact of equitable payment for watershed services scheme on livelihoods in Tanzania: the case of Uluguru Mountains. International Journal of Development and Sustainability 2(2): 1031-1051.

Mutiro, J. and J. Lautze. 2015. Irrigation in southern Africa: success or failure? Irrigation and Drainage 64(2): 180-192.

Mwendera, E. and P. Chilonda. 2013. Conceptual framework for revitalisation of small-scale irrigation schemes in Southern Africa. Irrigation and Drainage 62(2): 208-220. 
Oates, N., G. Jobbins, B. Mosello and J. Arnold. 2015. Pathways for irrigation development in Africa - insights from Ethiopia, Morocco and Mozambique. Future Agricultures Consortium Working Paper, No. 119. Brighton: Future Agricultures Consortium.

Peluso, N. and C. Lund. 2011. New frontiers of land control: introduction. The Journal of Peasant Studies 38(4): 667-681. Researchgate

Peters, P. 2013. Conflicts over land and threats to customary tenure in Africa. African Affairs 112(449): 54363.

Potkanski, T. and W.M. Adams. 1997. Water scarcity, property regimes and irrigation management in Sonjo, Tanzania. Journal of Development Studies 34(4): 86-116.

Riel, C. 2013. More than money: moral dynamics of farmers' engagement with a payment for environmental services scheme in the Uluguru Mountains, Tanzania. Masters Thesis, Department of Anthropology, University of Copenhagen.

Roe, E. 1994. Narrative policy analysis: theory and practice. Durham, NC: Duke University Press.

Sakaki, M. and K. Koga, 2013. An effective approach to sustainable small-scale irrigation developments in sub-Saharan Africa. Paddy Water Environment 11(1): 1-14.

Scoones, I., R. Smalley, R. Hall and D. Tsikata. 2014. Narratives of scarcity: understanding the 'global resource grab'. Future Agricultures Consortium Working Paper No.76. Brighton: Future Agricultures Consortium.

Smiley, S.L. 2013. Complexities of water access in Dar es Salaam, Tanzania. Applied Geography 41: 132138.

Suhardiman, D., and M Giordano. 2014. Is there an alternative for irrigation reform? World Development 57: 91-100. Researchgate

Tagseth, M. 2008. The expansion of traditional irrigation in Kilimanjaro, Tanzania. International Journal of African Historical Studies 41(3): 461-490.

Taylor, M. 2015. The political ecology of climate change adaptation: livelihoods, agrarian change and the conflicts of development. London and New York: Routledge

Temple, P.H. 1972. Soil and water conservation policies in the Uluguru Mountains, Tanzania. Geografiska Annaler 54(A): 157-193.

Tiffen, M. and M.J. Mortimore. 1994. Malthus controverted: the role of capital and technology in growth and environmental recovery in Kenya. World Development 22(7): 997-1010.

Ulvila, M. 1995. Learning with the villagers: an account of a participatory research in the Uluguru Mountains, Tanzania. Sosiologian ja sosiaalipsykologian tutkimuksia. Sarja A, No. 26. Tampere: University of Tampere.

UNR (no date) Leaflet from Uluguru Nature Reserve Office, Morogoro, Tanzania.

URT 2002. National Water Policy 2002. Dar-es-Salaam: Government of the United Republic of Tanzania.

URT 2009. The Water Resources Management Act 2009. Dar-es-Salaam: Government of the United Republic of Tanzania.

URT. 2010. The National Irrigation Policy. Dar-es-Salaam: Ministry of Water and Irrigation.

URT. 2013. National Census 2012. Dar-es-Salaam, Government of the United Republic of Tanzania.

van Koppen, B., C. Vladimir, and T. Skielboe. 2012. Project politics, priorities and participation in rural water schemes. Water Alternatives 5(1): 1-15.

van Koppen, B., A.K.P.R. Tarimo, A. van Eeden, E. Manzungu and P.M. Sumuni. 2016. Winners and losers in IWRM in Tanzania. Water Alternatives 9(3): 588-607.

van Donge, J.K. 1992. Agricultural decline in Tanzania: the case of the Uluguru mountains. African Affairs 362 (91): 73-94.

Veldwisch, G., A. Bolding and P. Wester. 2009. Sand in the engine: the travails of an irrigated rice scheme in Bwanje valley, Malawi. Journal of Development Studies 45(2): 197-226. 
Walsh, M. 2012. The not-so-Great Ruaha and hidden histories of an environmental panic in Tanzania. Journal of Eastern African Studies 6(2): 303-335.

Whitehead, A. and D. Tsikata, 2003. Policy discourses on women's land rights in Sub-Saharan Africa: the implications of the return to the customary. Journal of Agrarian Change 3(1-2): 67-112.

Wisner, B, A. Mascarehas, C. Bwenge, T. Smucker, E. Wangui, D. Weiner and M. Pantaleo. 2012. Let them eat (maize) cake: climate change discourse, misinformation and land grabbing in Tanzania. Article presented at the International Conference on Global Land Grabbing II October 17-19, 2012.

Woodhouse, P. 2012. New investment, old challenges: land deals and the water constraint in African agriculture. The Journal of Peasant Studies 39(3-4): 777-794.

Woodhouse, P., G.J.Veldwisch, J.P.Venot, D. Brockington, H. Komakech and A. Manjichi. 2017. African farmer-led irrigation development: re-framing agricultural policy and investment? The Journal of Peasant Studies 44(1): 213-233.

Wostry, A. 2014. An investigation of conservation measures and organic agriculture on the Uluguru Mountains. MSc thesis. Austria: University of Vienna. 